\title{
Persoalan Pendidikan Indonesia dalam Era Otonomi Daerah
}

\author{
Suyanto
}

After decentralization of law, regions have opening to reform a policy of local education for the answering of problems of education in the region. That changing of education policy is needed local human resources, who are creative, and have certain level of education because it needs autonomous of school as the smallest unit of education change.

\section{Pendahuluan}

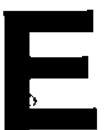

ra otonomi daerah yang diatur oleh Undang-Undang No. 22 tahun 1999 sudah berjalan hampir dua tahun. Dalam Undang-Undang tersebut, bidang pendidikan termasuk salah satu kewenangan pemerintah pusat yang ikut serta diotonomikan. Setelah otonomi pendidikan juga diberlakukan, ternyata banyak pihak, terutama sekolah dan juga pemerintah daerah yang belum memahami apa yang seharusnya dilakukan. Padahal, menurut ketentuan Undang-Undang No. 22 tahun 1999 banyak sekali yang seharusnya dilakukan oleh pemerintah daerah dalam mengelola pendidikan dasar dan menengah, baik dalam bidang manajemen, anggaran, kurikulum, pengawasan, evaluasi, pembinaan kariergunu, pengendalian kualitas, pendirian sekolah, dan sebagainya.

Pendidikan memiliki fungsi penting bagi daerah, terutama untuk peningkatan kualitas Sumber Daya Manusia (SDM). Daerah yang tidak memiliki SDM dan sumber dana yang memadai, dapat dipastikan tidak begitu mendukung program-program desentralisasi dalam bidang pendidikan. Sebab setelah pemerintah pusat memberikan otonomi kepada daerah, daerah memang harus lebih bersifat kreatif, mandiri, dan mampu mengembangkan daerahnya demi untuk kesejahteraan masyarakat melalui berbagai program pendidikan di daerahnya. Oleh sebab itu, dalam era otonomi pendidikan, daerah perlu membangun sektor pendidikan secara baik agar sektor ini mampu dijadikan penggerak bagi kemajuan daerah.

Meskipun demikian, membangun sektor Pendidikan tidak pernah akan mencapai tujuan akhir yang sempurna dan final. Hal ini terjadi karena konteks pendidikan selalu dinamik, berubah dan tidak pernah konstan, sesuai dengan perubahan masyarakat, ilmu pengetahuan dan teknologi. Terlebih-lebih dalam era informasi seperti saat ini keterbukaan di hampir semua aspek dan sistem kehidupan manusia tidak dapat dicegah lagi oleh kekuatan apapun. Hal ini membawa dampak pada cepat usangnya kebijakan maupun praksis pendidikan. 
Begitu pula parameter kualitas pendidikan, baik dilihat dari segi input, process, product, maupun outcome selalu berubah dari waktu ke waktu. Oleh sebab itu, pemerintah daerah secara terus-menerus perlu meningkatkan kualitas pendidikan di daerahnya, melalui sebuah sistem pembaharuan yang dapat dipertanggungjawabkan kepada para stakeholders agar dari sektor pendidikan itu kita mampu mempersiapkan generasi penerus yang memiliki unggulan kompetitif dalam menjawab dan memecahkan tantangan masa depan daerahnya sendiri. Keberhasilan bangsa ini menghadapi tantangan masa depan abad 21 sangat tergantung pada keberhasilan pemerintah daerah dalam memperbaiki dan memperbaharui proses dan hasil pembangunan sektor pendidikan saat ini.

Seiring dengan semangat reformasi nasional dalam bidang politik, ekonomi, dan hukum, otonomi daerah telah menjadi ketetapan dan kesepakatan nasional untuk dilaksanakan mulai bulan Januari 2001. Untuk menjamin semangat otonomi daerah memang telah diberlakukan UndangUndang No. 22 tahun 1999 (Undang-undang tentang Pemerintahan Daerah), UndangUndang No.25 Tahun 1999 (Undang-Undang tentang Perimbangan Keuangan antara Pemerintah Pusat dan Daerah). Undangundang tersebut juga dilengkapi dengan Peraturan Pemerintah No.25 Tahun 2000 (Perturan tentang Kewenangan Pemerintah dan Kewenangan Propinsi Sebagai Daerah Otonom). Pelaksanaan Undang-Undang tersébut membawa implikasi pada berubahnya setting pendidikan "baik di tingkat pusat maupun daerah. Sebelum era otonomi daerah, pendidikan menampilkan sosoknya dalam model yang sentralistik. Dalam sistem sentralistik yang telah diterapkan selama hampir setengah abad sejak Negara Republik Indonesia berhasil memperjuang- kan kemerdekaannya, pemerintah 'pusat memiliki peran yang amat penting dalam hampir semua perencanaan, implementasi, dan pengawasan kebijakan pendidikan. Untuk saat ini model seperti itu sudah tidak relevan lagi. Oleh sebab itu sudah merupakan kebutuhan yang amat mendesak bagi daerah untuk melakukan pembaharuan pendidikan agar pendidikan di daerah mampu menemukan relevansinya dengan sistem pemerintahan yang mendasarkan diri pada sistem desentralisasi.

Dalam era otonomi daerah seperti saat ini, pembaharuan pendidikan harus segera dilakukan agar masyarakat secara luas, keluarga, sektor swasta, politisi, dan juga unit-unit pemerintahan di semua tingkatan, akhirnya mampu memahami bahwa pendidikan merupakan human investment penting yang harus dirancang dan dibiayai secara lebih memadai agar bangsa ini mampu tumbuh dan bersaing dengan bangsa lain seiring dengan pertumbuhan dan proses demokratisasi dalam berbagai sistem kehidupan di Indonesia. Membangun pemahaman seperti ini memang tidak mudah karena sektor pendidikan tidak bersifat quick yield, sehingga kurang memberikan daya tarik bagi banyak pihak untuk memandang sektor pendidikan sebagai human investmentyang bersifat jangka panjang bagi proses peningkatan kualitas Sumber daya manusia di daerah.

Globalisasi, meskipun kadang-kadang telah dijadikan klise dalam suatu wacana, dampak dan pengaruhnya di bidang pendidikan tidak dapat dibendung oleh siapapun. Globalisasi melahirkan ukuran-ukuran baru, cara-cara baru, dan juga paradigma baru dalam memandang kualitas outcome pendidikan. Resep keberhasilan lama tidak akan dapat diulang lagi untuk meraih keberhasilan yang sama di era global seperti saat ini. Kualitas outcome pendidikan perlu mengacu pada ukuran-ukuran yang 
bersifat intemasional. Oleh karena itu quality assurance perlu ditegakkan dalam semua aspek yang mendukung proses pendidikan dalam arti yang luas agar pendidikan nasional mampu mempertahankan relevansinya terhadap tuntutan kualitas yang bersifat global. Dalam konteks globalisasi, daerah-daerah juga perlu melakukan benchmarking sektor pendidikan yang dikelolanya secara otonomi dalam aspek input, process, product, maupun outcome agar otonomi daerah tidak membuat sektor pendidikan justru menjadi ketinggalan jaman.

\section{Tantangan bagi Pemerintah Daerah}

Kualitas sumber daya manusia kita saat ini masih sangat rendah jika dibandingkan dengan negara-negara lain. Bahkan dengan sesama anggota negara ASEANpun kualitas SDM kita masuk dalam rangking yang rendah, jika diukur menggunakan Human Development Index yang diterbitkan oleh UNDP. Saat ini kita berada pada peringkat 109 dari 174 negara di dunia. Hal ini terjadi sebagai akibat kurang berfungsinya bidang pendidikan secara optimal untuk memberdayakan masyarakat secara keseluruhan. Rendahnya kualitas SDM kita berakibat pada rendahnya daya saing bangsa Indonesia di tengah-tengah percaturan global dalam berbagai aspek kehidupan. Hal ini juga akan dialami oleh daerah, manakala setelah era otonomi ini daerah tidak memperhatikan pembangunan sektor pendidikan. Jika pendidikan di daèrah tidak maju, dapat dipastikan dalam jangka panjang daerah yang bersangkutan tidak akan mampu menggali potensi daerah menjadi kekuátan aktual bagi daya saing däerah yang bersangkutan.

Salah satu penyebab mengapa bangsa Indonesia tidak mampu segera keluar dari krisis ekonomi, jika dibandingkan dengan negara-negara lain yang juga mengalami krisis ekonomi pada kurun waktu yang sama seperti Korea Selatan, Malaysia, Thailand, dan Pilipina, juga disebabkan oleh rendahnya kualitas SDM yang dimiliki. Rendahnya SDM ini, sekali lagi, sebagai akibat kurang relevannya program-program pembangunan pendidikan dalam menghadapi persoaian-persoalan yang dihadapi bangsa Indonesia dalam perspektif kekinian dan masa depan. Hal ini semua akan menjadi ancaman bagi keberlangsungan bangsa jika kita, mau tidak mau, harus bersaing secara terbuka pada tatanan dunia baru di era AFTA, NAFTA, dan APEC tahun 2020 nanti. Oleh karena itu agar pemerintah daerah mampu mengaktualisasikan potensi daerah menjadi kekuatan pembangunan yang riil, maka daerah harus bersedia melakukan investasi dalam bidang pendidikan secara memadai. Pendidikan di daerah perlu diperbaharui agar mampu melahirkan generasi daerah yang memiliki unggulan komparatif dan unggulan kompetitif yang tinggi pada era persaingan global seperti saat ini.

Dalam pembaharuan pendidikan, daerah otonom perlu membangun sistem pendidikan yang responsif terhadap perubahan dan tuntutan jaman sejak dari pra-sekolah, pendidikan dasar, dan pendidikan menengah. Jika demikian halnya, maka pembaharuan pendidikan di daerah perlu mencari rumusan, model, sistem, dan juga kebijakan yang mampu memberi peluang bagi berseminya motivasi, kreativitas, etos kérja, kejujuran, kedisiplinan, toleransi di tengah-tengah pluralitas etnis, agama, sosial, ekonomi, dan sebagainya, bagi semua peserta didik.

Pembaharuan pendidikan pada level daerah otonom, dengan demikian, menjadi bersifat imperatif bagi setiap upaya daerah untuk menggali dan mengem-bangkan berbagai potensi yang dimilikinya. Oleh karena itu agar pendidikan di daerah dapat ber- 
kembang dengan baik, dan dengan demikian memiliki dampak yang positif bagi pengembangan potensi daerah, maka pendidikan harus diberi kesempatan berkembang yang seluas-luasnya tanpa ada kebijakan satupun yang menghambatnya. Dengan demikian adanya gagasan untuk memungut pajak sektor pendidikan dalam jangka panjang justru akan menjadi kontraproduktif bagi pengembangan potensi daerah. Pajak bagi sektor pendidikan harus ditiadakan agar sektor ini dapat berkembang menopang perkembangan ekonomi dan potensi daerah secara riil.

Proses pendidikan sebenamya memiliki multiplier effect secara ekonomik. Jika pendidikan di daerah menjadi maju, memiliki kualitas yang unggul, secara tidak langsung daerah yang bersangkutan akan diuntungkan secara ekonomik. Kalau hal ini terjadi, berarti Pendapatan Asli Daerah (PAD) akan terdongkrak oleh karenanya. Jadi jika dilihat dari strategi peningkatan $P A D$, pendidikan sungguh merupakan sektor yang cukup strategis bagi daerah untuk dijadikan pilihan investasi ekonomik dalam jangka panjang, di samping pendidikan itu juga jelas-jelas sebagai human investment.

\section{Profesionalisme Layanan Pendidikan}

Pembangunan pendidikan di daerah dalam kerangka untuk menggali dan mengembangkan potensi yang dimilikinya perlu melahirkan profesionalisme. Dengan demikian berbagai resources yang ada di daerah akan dapat dikelola dan dikembangkan secara baik demi untuk kemakmuran masyarakat. Jika daerah ingin mengembangkan pendidikan secara profesional, ciri-ciri profesionalisme berikut perlu diindahkan, agar dunia pendidikan di aerah otonom tidak diisi dan dikelola oleh orang-orang yang tidak paham tentang substansi dan hakikat proses pendidikan itu sendiri. Ciri-ciri profe- sionalisme (Houle, 1980) bagi pengelola pendidikan yang dimaksud meliputi:

1. Harus memiliki landasan pengetahuan yang kuat;

2. Harus berdasarkan atas kompetensi individual;

3. Memiliki sistem seleksi dan sertifikasi;

4. Ada kerjasama dan kompetisi yang sehat antar sejawat;

5. Adanya kesadaran profesional yang tinggi;

6. Memiliki prinsip-prinsip etik (kode etik);

7. Memiliki sistem sanksi profesi;

8. Adanya militansi individual;

9. Memiliki organisasi profesi.

Banyak kajian tentang otonomi bidang pendidikan dengan tujuan untuk melakukan reformasi dalam bidang pendidikan dalam skala nasional, pada lingkup pemerintah (pusat) dan daerah (pemerintah kota dan kabupaten). Dari berbagai kajian dapat ditarik benang merah yang jelas bahwa kunci keberhasilan otonomi bidang pendidikan terletak di unit otonom yang terkecil, yaitu sekolah. Itulah sebabnya, Sirotnik dan Clark (1988) berujar: "The ultimate power to change is -and always been - in the heads, hands, and hearts of the educators who work in the schools."

Menurut pengalaman 'negara-negara maju, paling tidak ada delapan tujuan yang saling berkaitan yang kemudian akan mendorong terjadinya perubahan dan pembaharuan (reformasi) pendidikan, yaitu: (1) akselerasi pembangunan ekonomi melalui modernisasi institusi, (2) peningkatan efisiensi manajemen, (3) realokasi tanggungjawab keuangan (dari pusat ke daerah), (4) penumbuhkembangan demokrasi, (5) peningkatan pengawasan oleh daerah melalui deregulasi, (6) pengenalan sistem pendidikan berdasarkan kekuatan pasar, (7) netralisasi kompetisi antar pusat kekuatan yang berpengaruh pada sektor pendidikan, dan (8) peningkatan kualitas pendidikan. 
Kita sebagai bangsa yang baru belajar melakukan otonomi bidang pendidikan perlu kiranya menyimak pengalaman negara-negara maju yang telah lebih dulu melakukannya. Delapan tujuan yang mampu mendorong terjadinya peru-bahan di bidang pendidikan dalam konteks desentralisasi seperti tersebut di atas perlu kita cermati baik di tingkat pemerintah (pusat) maupun di tingkat propinsi, kabupaten, dan kota. Hal ini menjadi penting agar tidak terjadi kompetisi pusat kekuasaan (pendidikan) sehingga dengan adanya desentralisasi ini justru muncul bentuk dan praktik sentralisasisentralisasi baru yang lebih banyak dan lebih kecil di berbagai daerah otonom. Kalau hal ini sampai terjadi, tujuan desentralisasi akan tidak tercapai. Bahkan kejelekankejelekan sentralisasi (tunggal) yang dulu per-nah terjadi justru akan terjadi dan terulang lagi pada sentral-sentral baru, yaitu di kabupaten dan kota; Dengan demikian birokrasi akan lebih kaku dan akan menampilkan bentuk rigiditas yang beragam, sehingga sulit dicari pola pembenahannya di tingkat nasional (pusat) maupun daerah. Dengan kondisi seperti itu reformasi pendidikan tidak akan dapat terjadi, dan akhimya yang akan menjadi korban adalah masyarakat itu sendiri dan peserta didik di daerah-daerah otonom.

Untuk menghindari hal itu, ada paling. tidak delapan hal yang dapat dilakukannya, yaitu:

Pertama, awali dengan analisis yang mendalam terhadap sistem pendidikan yang sedang berlangsung di daerah masingmasing. Pengambil kebijakan di tingkat pemerintah daerah akan dapat melakukan reformasi pendidikan jika mereka memahami dengan sesungguhnya kekuatan dan kelemahan sistem yang ada. Persoalan yang terkait dengan efisiensi manajemen, kapasitas untuk berubah, anggaran pendidikan, sistem informasi, relevansi kurikulum dengan perkembangan dan kebutuhan masyarakat, kualitas pembelajaran, dan peranserta masyarakat perlu dikaji secara seksama.

Kedua, pahami tujuan-tujuan pendidikan yang dapat mendorong terjadinya perubahan baik yang tertulis maupun yang tidak tertulis (tersurat dan tersirat). Tujuan ini kemudian perlu-disosialisasikan kepada aktor-aktor kunci pendidikan agar terjadi perubahan yang signifikan. Oleh karena itu, guru, keluarga, penguasa dan pengambil kebijakan pendidikan, di daerah otonom harus memahami tujuan pendidikan di daerahnya masing-masing.

Ketiga, kembangkan dan rumuskan visi pendidikan yang dapat dipahami oleh semua aktor pendorong perubabahan pendidikan. Pemahaman terhadap visi pendidikan di tingkat sekolah dan pemerintah daerah kabupaten atau kota sangat penting agar tidak terjadi konflik antar pusat kekuatan. Dengan pemahaman visi pendidikan itu diharapkan akan terjadi kolaborasi antar pusat-pusat kekuatan, sehingga akan mendorong perubahan dan reformasi pendidikan ke arah dan tujuan yang telah disepakati bersama.

Keempat, siapkan perencanaan pengembangan bidang pendidikan yang jelas dan realistik. Kita harus mampu membedakan mana program yang feasible bagi pendidikan di daerah. Jangan terjebak pada pengembangan perencanaan pendidikan yang tidak realistik, tidak membumi, dan dengan demikian hanya bersifat desirable. Perencanaan yang jelas dan realistik itu perlu mempertimbangkan berbagai prakondisi yang harus dimiliki untuk menjamin terjadinya perubahan. Prakondisi yang harus disiapkan itu meliputi aspekaspek: pelatihan kepemimpinan bidang pendidikan di tingkat nasional dan lokal, penggantian guru dan personel pendidikan yang akan dan telah pensiun, memodifikasi 
cara-cara pengambilan keputusan, dan sebagainya.

Kelima, lakukan analisis fungsi organisasi dan manajerial seawal mungkin. Hal ini perlu dilakukan karena harus adanya perubahan dan pergeseran peran maupun fungsi organisasi pendidikan dalam melaksanakan tugas-tugas yang desentralistik. Dengan cara ini kita akan mendapatkan organisasi yang fungsional dalam rangka mendapatkan the right man in the right place, sehingga tidak akan terjadi penempatan orang yang tidak paham semasekali akan urusan pendidikan menjadi Kepala Dinas Pendidikan dalam era desentralisasi pendidikan. Fenomena penempatan pejabat bidang pendidikan yang tidak memperhatikan prinsip profesionalisme banyak terjadi di berbagai daerah. Dalam jangka panjang daerah yang melakukan hal itu akan menuai kerugiannya dalam bidang peningkatan kualitas sumber daya manusia di daerahnya masing-masing.

Keenam, limpahkan kewenangan secara bertahap. Hal ini penting agar tidak terjadi kemacetan fungsi layanan publik di bidang pendidikan. Perubahan dan praktik baru dalam bidang manajemen dan organisasi pendidikan tidak dapat disulap dalam waktu dua puluh empat jam. Perubahan itu mengandung proses adopsi sebuah inovasi. Tidak semua orang suka pada perubahan. Jack Welch, seorang Chief Executive perusahaan raksasa kelas dunia, General Electric, menggambarkan betapa perubahan pada hakikatnya tidak disukai oleh banyak orang. Fenomena itu digambarkan dalam ungkapannya sebagai berikut: "Change has no constituency. People like status quo. They like the way it was".

Ketujuh, biasakan dan budayakan untuk melakukan pembagian kekuasaan (power sharing). Dengan melakukan pembagian kekuasaan, dapat diciptakan budaya kerja yang sinergis. Cara ini akan lebih efektif untuk menghadapi tantangan pendidikan eksternal maupun internal yang muncul di daerah. Power sharing dapat mendorong adanya kolaborasi yang positif dalam konteks inter dan antar elemen-elemen organisasi pendidikan, dan dengan demikian juga akan mendorong adanya resource sharing yang amat efektif untuk memecahkan kelangkaan dana, infra struktur, dan sumber daya manusia di daerah.

Akhirnya, budayakan semua unsur yang ada di sektor pendidikan untuk mampu berpikir jangka panjang. Otonomi pendidikan tidak akan beres dengan hanya diundangkannya UU No. 22 dan No.25 thun 1999. Lebih dari itu pengambil kebijakan yang ada di sektor pendidikan harus mampu berpikir jangka panjang demi kepentingan daerah dalam kerangka Negara Kesatuan Republik Indonesia. Terlebihlebih, pembangunan dan pengembangan sektor pendidikan tidak akan mampu menunjukkan hasilnya dalam jangka pendek seperti menanam melon, pisang, jagung, atau padi. Pembangunan pendidikan baru akan menunjukkan hasilnya secara nyata, jika itu berhasil, paling tidak 20 tahun kemudian. Kalau para pengambil kebijakan tidak memiliki pemikiran jangka panjang, tidak akan terjadi investasi dan inovasi di bidang pendidikan di daerah otonom.

\section{Manajemen Berbasis Sekolah}

Dalam era otonomi daerah, pendidikan perlu dikelola dengan memper-hatikan kepentingan sekolah itu sendiri untuk berkembang secara optimal dan mandiri. Oleh karena itu, manajemen berbasis sekolah merupakan pilihan yang baik untuk dilakukan oleh pemerintah daerah. Meskipun demikian, otonomi sektor pendidikan akan memasuki kondisi yang membahayakan jika tidak ada proses penanganan yang sinergis antara pemerintah pusat dan 
daerah. Saat ini pemerintah daerah memiliki eforia yang sangat tinggi, sehingga secara subyektif merasa sudah siap untuk mengelola pendidikan yang ada di daerahnya masingmasing tanpa melakukan refleksi dengan cara: mencermati kelemahan, kelebihan, dan peluang yang mungkin ada di daerahnya masing-masing. Oleh karena itu kesiapan daerah saat ini sebenamya ban menupakan kesiapan psikologis. Kesiapan teknis dan profesional masih perlu dipertanyakan.

Dalam kerangka otonomi pendidikan, manajemen pendidikan berbasis sekolah dapat dimanfaatkan sebagai salah satu pendekatan yang mampu menjanjikan peningkatan kualitas dan relevansi pendidikan di setiap daerah. Meskipun demikian, pelaksanaan model menajemen ini perlu didukung oleh berbagai persyaratan profesional sumber daya manusia, lingkungan sekolah dan masyarakat yang kondusif bagi bekerjanya prinsip-prinsip manajemen berbasis sekolah. Tanpa ada daya dukung dari komunitas sekolah dan masyarakat, manajemen berbasis sekolah tidak akan mampu meningkatkan kualitas sekolah dalam konteks desentralisasi pendidikan.

Manajemen berbasis sekolah, dalam konteksotonomi pendidikan, bukan berarti daerah harus bebas sekali -terlepas dari pengaruh pemerintah pusat. Bahkan untuk masa awal otonomi pendidikan seperti saat ini daerah perlu menjalin hubungan konsultatif yang bersifat sinergis dengan pemerintah pusat agar pelaksanaan manajemen berbasis sekolah dapat dilakukan dengan efektif. Memang benar bahwa pemerintah pusat selama tiga puluh tahun di era Orde Baru kurang, dan bahkan dapat dikatakan belum berhasil mengangkat kualitas pendidikan di Indonesia. Namun, pemerintah pusat dalam arti sistem sentralistiknya memiliki pengalaman dalam mengelola pendidikan. Pengalaman itu -memang tidak semuanya baik, dan bahkan banyak yang tidak baik. Pengalaman yang baik itulah yang masih dapat dimanfaatkan oleh sekolah di era otonomi seperti sistem rekrutmen guru dan siswa, penempatan personalia, pengembangan kurikulum untuk kepentingan daerah, dan sebagainya. $\mathrm{Hal}$ ini perlu diperhatikan karena dengan adanya desentralisasi pendidikan, sudah banyak pemerintah daerah yang mewacanakan untuk hanya mempekerjakan guru yang berasal dari daerahnya sendiri - sehingga yang penting bagi daerah adalah Putra Asli Daerah, dan menempatkan pejabat-pejabat bidang pendidikan yang tidak memiliki latar belakang pendidikan sesuai dengan persyaratan kualifikasi profesionalisme. Kalau hal ini terus menerus terjadi, sungguh kondisi yang kondusif bagi implementasi manajemen berbasis sekolah tidak akan dapat tenwujud. Guru seharusnya lintas lokasi, etnis, dan lintas agama, dan tanpa memandang putra daerah atau tidak. Kalau semua daerah berpikiran bahwa guru harus berasal dari daerahnya masing-masing, dalam jangka panjang akan merugikan sekolah di daerah itu sendiri. Dengan analogi yang sama, proposisi tersebut juga berlaku untuk rekrutmen siswa.

Manajemen pendidikan berbasis sekolah memberikan otonomi yang luas kepada kepala sekolah, sehingga kepala sekolah harus berani mengambil keputusan secara lebih otonom dengan menggunakan gaya kepemimpinan yang partisipatif. Dalam pengambilan keputusan yang partisipatif tersebut kepala sekolah perlu melibatkan semua komponen komunitas sekolah: guru, siswa, kepala sekolah, pegawai, orangtua siswa, dan masyarakat secara fungsional. Artinya unsur-unsur komunitas sekolah tersebut diberi peluang dan diajak untuk memikirkan kemajuan sekolah dan peningkatan mutu sekolah melalui kontribusi masing-masing sesuai dengan kapasitasnya. Dengan demikian para pendidik yang ada di sekolah sangat menentukan 
perubahan sekolah itu sendiri ke arah yang lebih baik dan lebih berkualitas. Dalam melaksanakan manajemen pendidikan berbasis sekolah kepala sekolah perlu memiliki kepemimpinan yang kuat, partisipatif, dan dengan demikian demokratik. Untuk mengakomodasikan persyaratan ini kepala sekolah dapat mengadopsi pola kepemimpinan transformasional. Kepemimpinaan transformasional dapat didefinisikan sebagai gaya kepemimpinan yang mengutamakan pemberian kesempatan dan atau mendorong semua unsur atau komponen yang ada dalam sekolah seperti: guru, siswa, kepala sekolah, pegawai, orangtua siswa, dan masyarakat untuk bekerja atas dasar sistem nilai yang luhur sehingga semua unsur yang ada tersebut bersedia berpartisipasi secara optimal dalam mencapai tujuan ideal sekolah.

Ciri seorang yang telah berhasil menerapkan gaya kepemimpinan transformasional, menurut Luthans, (1995: 358) adalah sebagai berikut:

a. mengidentifikasikan dirinya sebagai agen perubahan (pembaruan);

b. memiliki sifat pemberani;

c. mempercayai orang lain;

d. bertindak atas dasar sistem nilai, (bukan atas dasar kepentingan individu, atau atas dasar kepentingan dan desakan kroninya);

e. meningkatkan kemampuannya secara terus-menerus sepanjang hayatnya;

f. memiliki kemampuan untuk menghadapi situasi yang rumit, tidak jelas, dan tidak menentu;

g. memiliki visi ke depan.

Manajemen pendidikan berbasis sekolah jika diterapkan dengan tepat akan dapat membuat sekolah menjadi efektif. Sekolah yang efektif mampu mendorong belajar bagi semua siswa, baik yang fast learners maupun yang slow learners. Sekolah yang tidak efektif hanya mampu mendorong belajar anak-anak yang pandai saja. Sebaliknya, anak-anak yang kurang beruntung, slow learners, tidak akan mendapatkan kesempatan untuk berkembang secara optimal sesuai dengan kemampuannya. Definisi sekolah yang efektif menurut Mortimore (1991:9) adalah: "one in which students progress further than might be expected from a consideration of - intake". Dalam sekolah yang efektif terdapat proses belajar yang efektif, yang ciri-cirinya menurut Mortimore adalah sebagai berikut:

1. Active rather than passive;

2. Covert rather than overt;

3. Complex rather than simple;

4. Affected by individual differences amongst learners;

5. Influenced by a variety of contexts.

Selanjutnya, sekolah yang efektif, menunut Sackney (1986) mampu mewujudkan adanya misi, iklim belajar, proses belajar, yang secara rinci dapat dikelompokkan sebagai berikut:

1. A Common Mission:

a. Shared values and beliefs;

b. Clear Goals;

c. Instructional Leadership;

2. A Climate conductive to learning:

a. Student Involvement and responsibility;

b. Physical environment;

c. Positive student behavior;

d. Parental and community involvement and support;

3. Emphasis on Learning:

a. Instructional and Curriculum Focus;

b. Teacher collegiality and development;

c. High expectations;

d. Frequent monitoring of student progress.

Pada hakikatnya, manajemen pendidikan berbasis sekolah sebagai konsep dan paradigma baru, dalam pelaksanaannya perlu melalui berbagai tahapan. Karena 
merupakan paradigma baru, implementasinya perlu memperhatikan kemungkinankemungkinan bagi sekolah untuk mau mengadopsinya. Dengan demikian, pelaksanaan manajemen pendidikan berbasis sekolah dapat dikategorikan sebagai proses inovasi pendidikan. Sebagai inovasi, dengan demikian, keberhasilan pelaksanaan atau implementasi manajemen pendidikan berbasis sekolah masih banyak ditentukan oleh berbagai faktor sebagaimana diteorikan oleh Carlson. Menurut Carlson (1965) keberhasilan inovasi dalam bidang pendidikan masih akan ditentukan oleh lima karakteristik dari program yang diinovasikan, yaitu:
a. Relative advantage;
b. Compatibility;
c. Complexity;
d. Divisibility;
e. Communicability.

Sejalan dengan teori adopsi inovasi dari Carlson tersebut tahapan pelaksanaan manajemen pendidikan berbasis sekolah telah pula dirumuskan oleh Depdiknas, Direktorat Jenderal Pendidikan Dasar dan Menengah, Direktorat Sekolah Lanjutan Pertama (2001: 29- 46) yang mencakup langkah-langkah sebagai berikut:

a. Melakukan Sosialisasi;

b. Mengidentifikasi Tantangan Nyata Sekolah;

c. Merumuskan Visi, Misi, Tujuan, dan Sasaran Sekolah;

d. Mengidentifikasi Fungsi-Fungsi yang Diperlukan untuk Mencapai sasaran;

e. Melakukan Analisis SWOT;

f. Alternatif Langkah Pemecahan Persoalan;

g. Menyusun Rencana dan Program Peningkatan Mutu;

h. Melaksanakan Rencana Peningkatan Mutu;

i. Melakukan Evaluasi Pelaksanaan;

j. Merumuskan Sasaran Mutu Baru.
Manajemen pendidikan berbasis sekolah di negara-negara lain juga telah terbukti keefektifannya dalam meningkatkan kualitas sekolah di pemerintah daerah secara otonom. Banyak penelitian, secara konklusif, mendukung rasionel efektivitas penggunaan manajemen pendidikan berbasis sekolah. Para peneliti tersebut antara lain: Amundson (1988); Burns and Howes (1988); David and Peterson (1984); English (1989); Levine and Eubank (1989); Lindelow and Heynderickx (1989); Malen, Ogawa, and Kranz (1990a,b); Marburger (1985); Mojkowski and Fleming (1989); Peterson (1991); and White (1989) (http://www.nwrel.org/). Hasilhasil penelitian yang mereka lakukan tersebut memberikan kesimpulan yang mendukung diterapkannya manajemen pendidikan berbasis sekolah, dengan berbagai argumentasi sebagai berikut:

a. sekolah merupakan suatu sarana utama untuk melakukan perubahan

b. Orang yang bekerja secara langsung dengan peserta didik betul-betul yang memiliki pandangan-pandangan yang dapat dipercaya mempunyai informasi secara baik untuk menangani masalah kependidikan yang dapat memberikan manfaat bagi para peserta didik.

c. Perbaikan yang signifikan terjadi dengan mempertimbangkàn waktu, lokasi sekolah adalah posisi yang paling baik untuk mempertahankan upayaupaya perbaikan melampaui waktu.

d. Kepala sekolah merupakan tokoh kunci dalam pengembangan sekolah.

e. Perubahan yang signifikan yang dilakukan oleh staf dan partisipasi masyarakat dalam proyek perencanaan dan implementasinya.

i. Manajemen berbasis sekolah mendukung profesionalisasi profesi pengajaran dan sebaliknya, yang dapat mengarahkan lulusan.

g. Struktur Manajemen berbasis sekolah dapat menjaga tujuan pembelajaran 
yang dimilikinya dalam pencapaian dan lulusan-lulusan peserta didik lainnya.

h. Dukungan antara dana dan prioritas yang bersifat instruksional dapat meningkat berdasarkan manejemen berbasis sekolah.

\section{Daftar Bacaan}

Carlson, R.O. (1965). Adoption of Education Innovations. Eugene, Oregon: the Center for the Advance Study of Educational Administration, University of Oregon.

Cotton, K. (2001) "School-Based Management" in School Improvement Research Series. http:// www.nwrel.org/scpd/sirs/7/ topsyn6.html.
Direktorat Sekolah Lanjutan Tingkat Pertama (2001). Manajemen Peningkatan Mutu Berbasis Sekolah: Buku 1 Konsep dan Pelaksanaan. Jakarta: Departemen Pendidikan Nasional.

Houle, C.O. (1980). Continuing Leaming in The Professions. San Francisco: Jossey-Baas Publisher.

Luthans, F. (1995). Organizational Behavior (7th ed.) New York: McGraw-Hill, Inc.

Mortimore, P. (1993). "School Effectiveness and the Management of Effective Learning and Teaching". School Effectivenss and School Improvement. Vol.4, No. 4, pp. 290-310.

Sackney, L. (1986). "Practical Strategies for Improving School Effective-ness". The Canadian School Executive, Vol. 6, No.4 pp. 15-20. 